\title{
Spatial mapping and analysis
}

\author{
Graeme S. Cumming ${ }^{1}$ and Ralf Seppelt ${ }^{2,3}$
}

${ }^{1}$ ARC CENTRE OF EXCELLENCE FOR CORAL REEF STUDIES, JAMES COOK UNIVERSITY, TOWNSVILLE, AUSTRALIA ${ }^{2}$ UFZ - HELMHOLTZ CENTRE FOR ENVIRONMENTAL RESEARCH, DEPARTMENT OF COMPUTATIONAL LANDSCAPE ECOLOGY, LEIPZIG, GERMANY

${ }^{3}$ INSTITUTE OF GEOSCIENCE AND GEOGRAPHY, MARTIN LUTHER UNIVERSITY HALLE-WITTENBERG, HALLE, GERMANY

\section{Key methods discussed in this chapter}

Spatial mapping and analysis, including geography, landscape ecology, remote sensing, statistics, land surveying, brief overview of relevant mapping and analytical approaches

\section{Connections to other chapters}

This chapter connects to many others through the fundamental properties of location, connectivity and context. Spatial mapping is used to bound study systems, and any analysis for which the location, context or connectivity of an element or phenomenon is relevant requires familiarity with these methods. Chapters on statistics (Chapter 18), network analysis (Chapter 23), agent-based modelling (Chapter 28), participatory data collection (Chapter 8), participatory modelling (Chapter 13), ecosystem service modelling (Chapter 31), historical assessment (Chapter 25) and ecological field data collection (Chapter 6) are particularly relevant.

\section{Introduction}

Space is part of the fabric of our existence. We live in four dimensions: time, and three dimensions of space. We can exist in only one location at any point in time. Space is the matrix in which we live. Any analysis can be conducted spatially and every problem has spatial elements. The key questions are (a) whether there are occasions on which one can safely ignore the spatial elements of a problem, and (b) what one loses by ignoring them.

Spatial mapping and analysis are among the oldest scientific techniques in social-ecological systems (SES) research, dating back to early biogeographic analyses of plant kingdoms and the relevance of ecological variation for human agriculture (Von Humboldt and Bonpland 1807; reprint 2010). The disciplines of geography, biogeography and landscape ecology focus on the relevance of spatial variation, spatial context and spatial location as influences on abiotic, biotic and anthropogenic patterns and processes (Turner, Gardner, and O'Neill 2001). A comparison of maps from two different points in time is a long-standing approach to exploring temporal change, dynamics and social-ecological feedbacks. 


\begin{tabular}{|c|c|}
\hline \multicolumn{2}{|c|}{ SUMMARY TABLE: SPATIAL MAPPING AND ANALYSIS } \\
\hline DISCIPLINARY BACKGROUND & KNOWLEDGE TYPE \\
\hline $\begin{array}{l}\text { The methods in this chapter are derived from } \\
\text { or have most commonly been used in: } \\
\text { Land Surveying, Geography, Landscape } \\
\text { Ecology, Remote Sensing, Statistics }\end{array}$ & $\begin{array}{l}\text { The methods in this chapter are primarily } \\
\text { used to generate the following types of } \\
\text { knowledge: } \\
\text { - Descriptive } \\
\text { - Exploratory } \\
\text { - Explanatory } \\
\text { - Prescriptive }\end{array}$ \\
\hline RESEARCH APPROACH & PURPOSE OF METHOD \\
\hline $\begin{array}{l}\text { The methods in this chapter originate from } \\
\text { or most commonly adopt the following } \\
\text { research approaches: } \\
\text { - Analytical/objective }\end{array}$ & $\begin{array}{l}\text { The most common purposes of using the } \\
\text { methods in this chapter are: } \\
\text { - Data collection/generation } \\
\text { - System understanding } \\
\text { - Stakeholder engagement and co- } \\
\text { production } \\
\text { - Policy/decision support }\end{array}$ \\
\hline TEMPORAL DIMENSION & SYSTEMIC FEATURES AND PROCESSES \\
\hline $\begin{array}{l}\text { The methods in this chapter are most } \\
\text { commonly applied to the following temporal } \\
\text { dimensions: } \\
\text { - Present (typically within the last } \\
5-10 \text { years) } \\
\text { - Recent past (post-1700s) } \\
\text { - Pre-industrial revolution (pre-1700s) } \\
\text { - Future }\end{array}$ & $\begin{array}{l}\text { While most methods can do many things, } \\
\text { the methods in this chapter are particularly } \\
\text { good (i.e. go-to methods) for addressing the } \\
\text { following: } \\
\text { - SES components and linkages } \\
\text { - Diversity } \\
\text { - Social-ecological interactions over time } \\
\text { - Regime shifts }\end{array}$ \\
\hline SPATIAL DIMENSION & \\
\hline $\begin{array}{l}\text { The methods in this chapter are primarily } \\
\text { either or both: } \\
\text { - Explicitly spatial } \\
\text { The methods in this chapter are most } \\
\text { commonly applied at the following } \\
\text { spatial scales: } \\
\text { - Local } \\
\text { - Regional (provincial/state } \\
\text { to continental) } \\
\text { - Global }\end{array}$ & \\
\hline
\end{tabular}


Recent technological advances in collecting and analysing spatially explicit data (i.e. data associated with spatial coordinates), coupled with improved processing capabilities, have led to a rapid and potentially overwhelming explosion of both data and methods for spatial analysis and mapping. High-resolution, broad-extent spatial and temporal datasets for biophysical variables are now available for periods of approximately 50 years. Mapping of human elements of SES has also improved through using the Internet and mobile devices to map spatial and temporal patterns in human demography, preferences, resource use and movements. Census data in many countries are now linked to zip codes or survey districts through a geographic information system (GIS), for example. By virtue of their shared location in space, these datasets can be rapidly linked to satellite-derived maps of the biophysical system to explore relationships and social-ecological feedbacks (Cord et al. 2017).

For the social-ecological researcher, the primary challenge in spatial mapping and analysis is less one of documenting patterns, which can be done in a wide variety of ways, and more one of inferring mechanisms. Spatial patterns arise from many different processes and it is easy to jump to false assumptions about cause and effect. People often assume, for example, that agglomeration, or clustering, in the distribution of organisms or businesses reflects the presence of clustered resources. But clustering may equally be produced by simple mechanisms, such as limited dispersal capacity and selective mortality, that have nothing to do with underlying resource availability (Skellam 1951). Ecologists and geographers use a variety of techniques, such as neutral landscape models, autocorrelation analysis and matching methods, to explore counterfactuals and to avoid going astray when testing hypotheses that have spatial elements (e.g. Gardner and Urban 2007; Geldmann et al. 2013). One of the core principles for good spatial analysis and mapping is that assumptions about spatial causality must always be treated as hypotheses and compared against other alternatives.

\section{SES problems and questions}

Spatial mapping is a common starting point for SES studies. Maps are used in nearly every SES study, whether explicitly or implicitly, to bound study areas, select and move between sampling locations, and identify important social and ecological heterogeneity within the study site. Biophysical variation in elevation, climate, water and soils drives patterns in human and ecological systems. The basic building blocks of ecological analysis are estimates of species diversity and the abundances of organisms; the units for these quantities are spatial and are estimated using spatially explicit techniques such as quadrats, line transects or camera traps. Similarly, most socio-economic studies occur in particular locations such as urban areas or villages; respondents for interviews and surveys are often selected based on their proximity to resources or their membership of a particular community; and in economic analyses, both market size and market access are heavily contingent on location, membership in spatial networks of supply and demand, and spatial context.

Spatial mapping and analysis can relate social and ecological elements of systems of interest. The use of tools for mapping and analysis depends to a very large extent on the goals of the analyst. Spatial relations may define or bound an analytical context (e.g. analysing water management approaches across different catchments), provide or inform mechanisms that explain outcomes of interest (e.g. understanding how household location influences ecosystem service preferences by people), or confound attempts to relate non-spatial variables in analyses of cause and effect (e.g. spatial patterns in household wealth and agricultural activity can make the influence of protected areas on nearby land prices harder to detect). Spatial 
relations are also important elements of comparative analyses across different case studies (Cumming 2011).

In SES research, spatial analysis and mapping have been widely used for the following: measuring changes in land use and land cover across landscapes; understanding abiotic, biotic and anthropogenic influences on ecosystems and exploring potential consequences of management actions; doing research on conservation planning and making decisions; and doing research that connects ecosystem services, land tenure and access to ecosystems and markets. Some published examples of social-ecological questions addressed by spatial approaches include:

- How does the success of a health-care intervention relate to household income in a fishing community? (Short et al. 2018)

- How should policy and management include animal movements? (Hays et al. 2019)

- How do governance institutions influence land-use change? (Holzhauer, Brown, and Rounsevell 2019)

- Does connectivity in marine reserve networks facilitate biodiversity conservation? (Magris et al. 2018)

- How does landscape structure affect ecosystem service delivery? (Ridding et al. 2018)

\section{Brief description of key methods}

The three dimensions of geographic space (longitude, latitude, elevation), plus the fourth dimension of time, provide a matrix in which we exist. Within this matrix, maps describe the coordinates of features or events in both space and time, providing a simplified record of reality. People create maps in a variety of ways and at scales ranging from molecular (e.g. 3D protein structures) to interstellar (e.g. star charts). Spatial analysis of any of these maps nonetheless has many shared ingredients, e.g. the use of coordinates, the calculation of basic spatial properties such as proximity or connectivity, and visualisation.

Autocorrelation is a particular concern in spatial analysis. It refers to the increased likelihood that values of a given variable at two points near each other in space will be similar to one another (Ord 2010). Most spatial datasets have autocorrelation. In some cases, autocorrelation is itself the variable of interest; in other cases, it is a nuisance variable that must be removed or factored out from the analysis, either statistically or through careful sampling. In SES research, spatial mapping and analysis typically use a GIS that provides an operational environment for spatial analyses, such as overlaying or intersecting polygons, extracting data from different data layers into a grid to create a comparable dataset, and smoothing or cleaning mapped data. In practice, GIS manipulation in a program like ArcGIS or Imagine is often a precursor to more intensive statistical analyses in other software packages (e.g. R, Matlab). Table 24.1 provides a summary of key applications of spatial mapping and analysis.

\section{Limitations}

Limits on spatial mapping and analysis are imposed by practical trade-offs between scale, processing time and information storage. The minimum mapping unit (MMU) is the size of the smallest feature that is reliably mapped by a given mapping approach. To distinguish between features requires a grain size (resolution) smaller than the MMU. Turner, Gardner and O'Neill (2001), for example, suggest that land-cover maps should have a grain at least three to five times smaller than the smallest patch and an extent three to five times larger than the 
Table 24.1 Summary of key applications of spatial mapping and analysis

\begin{tabular}{|c|c|c|}
\hline Main applications & Description & References \\
\hline Remote sensing & $\begin{array}{l}\text { Remotely sensed data typically take the } \\
\text { form of pictures of the earth's surface. } \\
\text { These data can be collected across a wide } \\
\text { variety of different wavelengths of radiation } \\
\text { (e.g. visible spectrum, ultraviolet, infra-red) } \\
\text { and either actively (using radar or LIDAR) } \\
\text { or passively (using sunlight, e.g. aerial } \\
\text { photography or satellite platforms such as } \\
\text { Landsat). After some processing to correct } \\
\text { for errors, noise and distortions, the typical } \\
\text { result is spatially explicit data at a consistent } \\
\text { extent and resolution, e.g. a single Landsat } \\
\text { Thematic Mapper (TM) image covers about } \\
250 \text { km² }^{2} \text { at a resolution of about } 30 \times 30 \text { m } \\
\text { (see also Chapter } 25 \text { : Historical assessment } \\
\text { and Chapter } 31 \text { : Ecosystem service } \\
\text { modelling). }\end{array}$ & $\begin{array}{l}\text { Key introductory text } \\
\text { Campbell and Wynne } 2011 \\
\text { Applications to SES } \\
\text { Jenerette et al. 2007; } \\
\text { Brody et al. 2008; } \\
\text { Lauer and Aswani 2008; } \\
\text { Kennedy et al. 2009; } \\
\text { Newton et al. 2009; } \\
\text { Ament and Cumming 2016; } \\
\text { Fernández-Giménez et al. } 2018\end{array}$ \\
\hline $\begin{array}{l}\text { Land-use and } \\
\text { land-cover } \\
\text { change analysis }\end{array}$ & $\begin{array}{l}\text { Land cover describes the nature of different } \\
\text { constituents of the earth's surface, such as } \\
\text { forest, grassland, water or built environment. } \\
\text { More specifically, land use refers to how } \\
\text { people use a parcel of land, e.g. a forest } \\
\text { (land cover) may be a conservation area or a } \\
\text { managed forest used for timber (land use). } \\
\text { Analysis of spatial patterns and changes } \\
\text { over time in land-use and land-cover } \\
\text { change (LULCC) are often used either as } \\
\text { explanations or as response variables in SES } \\
\text { analyses (see also Chapter 25: Historical } \\
\text { assessment and Chapter 31: Ecosystem } \\
\text { service modelling). }\end{array}$ & $\begin{array}{l}\text { Key introductory text } \\
\text { Lambin and Geist } 2008 \\
\text { Applications to SES } \\
\text { Veldkamp and Lambin 2001; } \\
\text { Agarwal et al. 2002; } \\
\text { Liu et al. 2007; } \\
\text { Meyfroidt et al. 2018; } \\
\text { Holzhauer, Brown, and } \\
\text { Rounsevell } 2019\end{array}$ \\
\hline Geostatistics & $\begin{array}{l}\text { Geostatistics is a branch of statistics } \\
\text { that developed in geology. It focuses } \\
\text { on measuring the strength of spatial } \\
\text { relationships. Geostatistics is used in } \\
\text { SES analysis for understanding spatial } \\
\text { pattern and autocorrelation, particularly } \\
\text { the spatial scale of autocorrelation in } \\
\text { point or continuous data, via semi- } \\
\text { variograms, correlograms and measures } \\
\text { of autocorrelation and dispersion such as } \\
\text { Moran's I or Ripley's K (see also Chapter 18: } \\
\text { Statistical analysis). }\end{array}$ & $\begin{array}{l}\text { Key introductory text } \\
\text { Isaaks and Srivastava } 1989 \\
\text { Applications to SES } \\
\text { Overmars, De Koning, and } \\
\text { Veldkamp 2003; } \\
\text { Mets, Armenteras, and } \\
\text { Dávalos 2017; } \\
\text { Fletcher and Fortin } 2018\end{array}$ \\
\hline
\end{tabular}


Main

applications

Species

distribution

models
Description

A species distribution model uses

observations of species of interest to

estimate the probability of species occurrence in geographic space. It is also used as a tool for understanding influences on species occurrences and for linking drivers of species distributions (e.g. physiological tolerance) to distributions. It uses a wide range of statistical tools, e.g. multiple regression, MaxEnt and discriminant analysis. A species distribution model is useful for SES analyses in which the spatial mapping of animal or plant habitat is relevant, e.g. estimating ecosystem service provision by hunted or harvested wild species, or looking at the potential sustainability of harvesting. These models also provide useful null hypotheses for understanding the impacts of human use, e.g. if suitable habitat is unoccupied as a consequence of over-harvesting or pollution (see also Chapter 18: Statistical analysis).

\begin{tabular}{|c|c|c|}
\hline Telemetry & $\begin{array}{l}\text { Telemetry uses trackable transmitters or } \\
\text { global positioning system (GPS) units } \\
\text { attached to animals or people to determine } \\
\text { where they go. It originally used radio- } \\
\text { frequency transmitting devices that were } \\
\text { tracked using a handheld antenna. The } \\
\text { most sophisticated approaches now use a } \\
\text { lightweight solar-powered satellite platform } \\
\text { terminal transmitter to transmit GPS data via } \\
\text { satellite (see also Chapter 6: Ecological field } \\
\text { data collection). }\end{array}$ & $\begin{array}{l}\text { Key introductory text } \\
\text { Hooten et al. } 2017 \\
\text { Applications to SES } \\
\text { Krause et al. 2013; } \\
\text { Lin et al. 2018; } \\
\text { Oppel et al. 2018; } \\
\text { Hays et al. } 2019\end{array}$ \\
\hline $\begin{array}{l}\text { Home range, } \\
\text { resource } \\
\text { selection and } \\
\text { utilisation } \\
\text { density analysis }\end{array}$ & $\begin{array}{l}\text { Home range, resource selection and utilisation } \\
\text { density analysis uses telemetry data to map } \\
\text { out which parts of a landscape are visited most } \\
\text { frequently by a tracked organism and where } \\
\text { key foraging areas and other vital elements } \\
\text { occur. It is useful for establishing how, when } \\
\text { and where animals and people use landscapes, } \\
\text { and is relevant in studies of human-wildlife } \\
\text { conflict (e.g. crop raiding in relation to human } \\
\text { diurnal rhythms, interactions of people and } \\
\text { carnivores, understanding locations of fishing } \\
\text { effort) (see also Chapter 18: Statistical analysis). }\end{array}$ & $\begin{array}{l}\text { Key introductory text } \\
\text { Moorcroft and Lewis } 2013 \\
\text { Applications to SES } \\
\text { Bodin et al. 2006; } \\
\text { Hebblewhite and Haydon 2010; } \\
\text { Zetterberg, Mörtberg, and } \\
\text { Balfors 2010; } \\
\text { Iwamura et al. } 2014\end{array}$ \\
\hline
\end{tabular}

References

Key introductory text

Franklin 2010

Applications to SES

Cumming and Van Vuuren 2006;

Sherrouse, Semmens, and

Clement 2014;

Uden et al. 2015;

Bonebrake et al. 2018 
Table 24.1 (Continued)

\begin{tabular}{|c|c|c|}
\hline $\begin{array}{l}\text { Main } \\
\text { applications }\end{array}$ & Description & References \\
\hline $\begin{array}{l}\text { Spatial } \\
\text { conservation } \\
\text { planning }\end{array}$ & $\begin{array}{l}\text { Spatial conservation planning uses spatially } \\
\text { explicit data layers of features of social, } \\
\text { ecological or economic interest to select } \\
\text { priority areas for conservation action. } \\
\text { Software such as MARXAN can take a large } \\
\text { number of individually mapped costs (e.g. } \\
\text { property prices) and benefits (e.g. recorded } \\
\text { occurrence of desirable habitat or species) } \\
\text { and find an optimal spatial solution given a } \\
\text { set of predefined constraints. } \\
\text { Conservation planning tools have broader, } \\
\text { but largely unexploited, applications in } \\
\text { spatial optimisation in SES. MARXAN, for } \\
\text { example, could easily be used to determine } \\
\text { areas of greatest value (given mapped } \\
\text { costs and benefits) for ecosystem service } \\
\text { production (see also Chapter 29: Decision } \\
\text { analysis based on optimisation). }\end{array}$ & $\begin{array}{l}\text { Key introductory text } \\
\text { Margules and Pressey } 2000 \\
\text { Applications to SES } \\
\text { Poiani et al. 2000; } \\
\text { Possingham, Ball, and Andelman } \\
2000 ; \\
\text { Pressey et al. 2007; } \\
\text { Ban et al. 2013; } \\
\text { Magris et al. } 2017\end{array}$ \\
\hline
\end{tabular}

largest patch. Maps with smaller grains usually have smaller extents. Obtaining a picture at finer grain size requires a closer or 'zoomed-in' lens; images that seek very high resolution at broad extents often run into a depth-of-field problem, which leads to blurring or very high levels of distortion at the edges. Also, information storage and processing demands increase rapidly with decreases in grain or increases in extent. Although Landsat Thematic Mapper images offer a good and widely used compromise $\left(30 \times 30 \mathrm{~m}\right.$ grain and c. $250 \mathrm{~km}^{2}$ extent $)$ for mapping vegetation and land-cover types, they cannot generally be used to map individual tree canopies, roofs or vehicles.

Satellite data are also limited, at present, to system elements that can be readily observed from the sky. Remote-sensing approaches for features that are under water (e.g. coral reefs, seagrass beds) are challenging and require special technologies. Approaches that ignore three-dimensional structure can result in fundamental errors, such as mapping urban tree canopies as forests or shade-grown coffee as pristine rainforest. Spatial analysis may be limited by a lack of data for features - like people and small animals (e.g. human attitudes, household incomes or distributions of rodents) - that cannot be sampled via satellite. Similarly, land use cannot always be reliably deduced from land cover. Most countries have a national data provider, such as the British Ordnance Survey, which assembles critical spatial data (e.g. economic zones, census data, farming types, cadastral data), but the information demands of SES research can be high and it is not uncommon for SES researchers to embark on intensive spatial data-collection programmes of their own.

\section{Resource implications}

Spatial mapping and analysis cover a broad spectrum of methodological complexity. Data visualisation and simple measures of distance or proximity can be undertaken over the 
Internet using freely available maps and software platforms provided by companies such as ESRI (esri.com/en-us/arcgis/products/index) and Google Maps (cloud.google.com/ maps-platform). By contrast, Google's Earth Engine (earthengine.google.com) provides a sophisticated online platform that effectively gives the user free access to a mainframe computer and a range of datasets through a low-speed desktop interface (developers. google.com/earth-engine/datasets). This can reduce the time demands of tasks that would currently take two to three months on a contemporary desktop machine to two to three days. Large quantities of high-quality data are also freely available from many nationallevel governmental programmes, such as the United States Geological Survey (USGS) and NASA.

There is an increasing trend towards open-source, shareware packages (e.g. QGIS) and the addition of GIS capabilities to statistical platforms such as $\mathrm{R}$ and Matlab. At the time of writing, we would still advocate undertaking standard GIS operations (e.g. visualisation, cleaning datasets, merging and joining, extracting information from raster layers into vector layers) in a GIS environment and then exporting cleaned datasets, in the desired format, for advanced statistical analysis into R. For field data collection, a wide variety of GPS-enabled hardware and software is now available including, for example, mobile phone technologies, GPS wristwatches and custom handheld GPS devices. These generally offer good accuracy to resolutions down to 5-10 $\mathrm{m}$, with some variation by location. For higher accuracy (e.g. submetre), a backpack GPS is still recommended.

Geographic information system analysis can be undertaken quite quickly and easily with relatively little training, and free online starter courses are available (e.g. via the ESRI website). A key point for SES research, and a particular trap for beginners, is that datasets should be critically examined and groundtruthed by using independent data from ground observations or field studies to verify datasets. 'Garbage in, garbage out' is a standard principle in GIS; using low-quality GIS data is easy and can rapidly produce advanced-looking maps. But if the data-collection protocol is weak, maps are poorly aligned and proper unbiased sampling approaches have not been observed (among other things), then the conclusions of the analysis will be unreliable.

\section{New directions}

Spatial mapping and analysis is a fast-moving research area that has progressed rapidly since the advent of modern computers and the Internet. New and exciting maps are increasingly being made available through new satellite platforms, new sensors and new platforms for carrying sensors (e.g. drones, solar-powered fliers, remotely operated vehicles (ROVs) and autonomous underwater vehicles (AUVs)). At the same time, data on human preferences and spatial movement patterns are increasingly becoming available via the widespread adoption and use of mobile phones, fitness devices and the Internet. Combining different data sources and data streams has huge and largely untapped potential for connecting human movement patterns and ecosystem access with human preferences (e.g. linking accommodation bookings, shopping data, entry to national parks, ecological interests and social network analysis via data from Internet search engines, mobile phone GPS and locations of connections made by mobile phone). Trasarti et al. (2015), for example, used mobile phone data to map movement patterns of people between Paris and surrounding rural areas over time, showing the role of key transport nodes. Technological advances are opening up new fields of analysis in SES research, such as participatory mapping to 


\section{Case study 24.1: Mapping a complex SES pattern for Germany}

The objective of this research was to understand how socio-environmental conditions influence the pattern and distribution of multiple ecosystem services. It thus exemplifies a spatially explicit SES and shows how ecosystem services bundles and associated socio-environmental gradients interrelate across Germany.

Eleven spatially explicit ecosystem service indicators of provisioning ecosystem services (crop, livestock, wood production, clean water), regulating ecosystem services (nitrogen and flood retention, erosion control, pollination potential) and cultural ecosystem services (water and landscape recreation) in Germany were synthesised using self-organising maps (Agarwal and Skupin 2008; Mouchet et al. 2014). Eight types of ecosystem services bundles (SEBs) were characterised to varying degrees for provisioning, cultural and regulating/maintenance services, and summarised in a spatially explicit map. To relate this to socio-economic drivers, 18 covariates were used (e.g. price of drinking water, employees, ratio female/ male, population density, etc. per district) to delineate socio-environmental clusters (Figure 24.2).

In Figure 24.1 the bar plots (so-called 'codebook vectors') show normalised values of the ecosystem services characterising each ecosystem services bundle, with zero representing the national average. The relative contribution of provisioning ecosystem services per ecosystem services bundle is indicated by the percentages next to the bar plots.

Figure 24.2 shows a mapped socio-environmental cluster (SEC). The bar plots show normalised values of covariates characterising each socio-environmental cluster, with zero representing the national average. Socio-environmental clusters are dominated either by socio-economic or environmental covariates. The relative contribution of these groups per socio-environmental cluster is indicated by the percentage next to the bar plots.

Overlaying these two maps provides information about the relationship between the spatial configuration of ecosystem services bundles and co-occurring socioenvironmental clusters (Figure 24.3). The clustering method of self-organising maps incorporates properties of each grid cell as well as its location and thus accounts for spatial auto-correlations.

Whereas ecosystem services bundles that were dominated by provisioning ecosystem services were linked to regions with distinct environmental characteristics, cultural ecosystem services bundles were associated with areas where environmental and socio-economic gradients had equal importance. This regional concentration of specific provisioning services probably reflects the ongoing specialisation in land use and especially in agricultural production, which accelerated around 1950. A hotspot for tourism was found next to the shoreline in northern Germany, where high values for recreation relate to the scenic beauty of the sea. Large areas along the coastline in Germany have been designated as national parks and other protected areas, providing infrastructure for nature appreciation and protection of resting places 
(A)
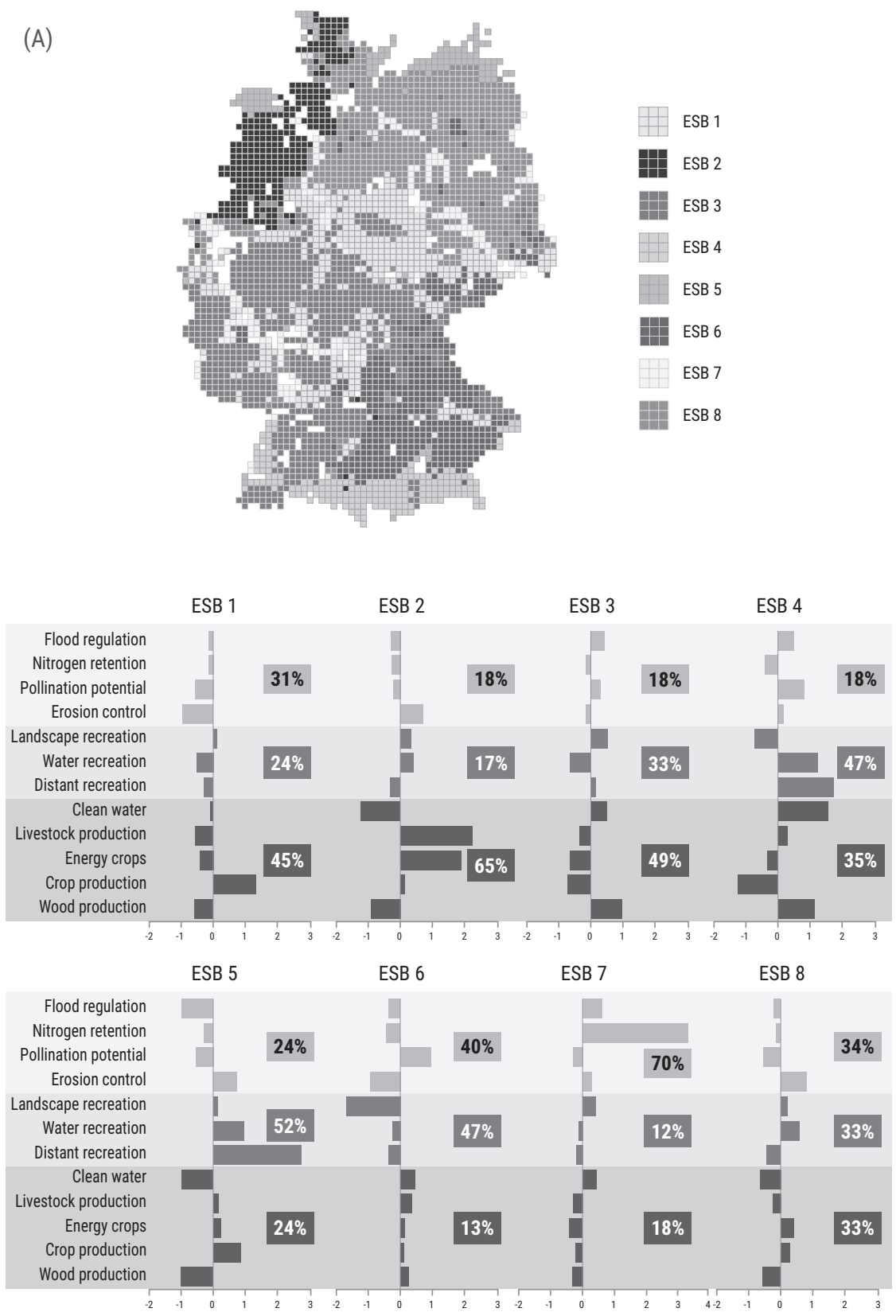

Figure 24.1 Ecosystem services bundles (ESBs) mapped in Germany (Dittrich et al. 2017; arcg.is/1C81jD) (@ Ralf Seppelt)

(Continued) 
(B)
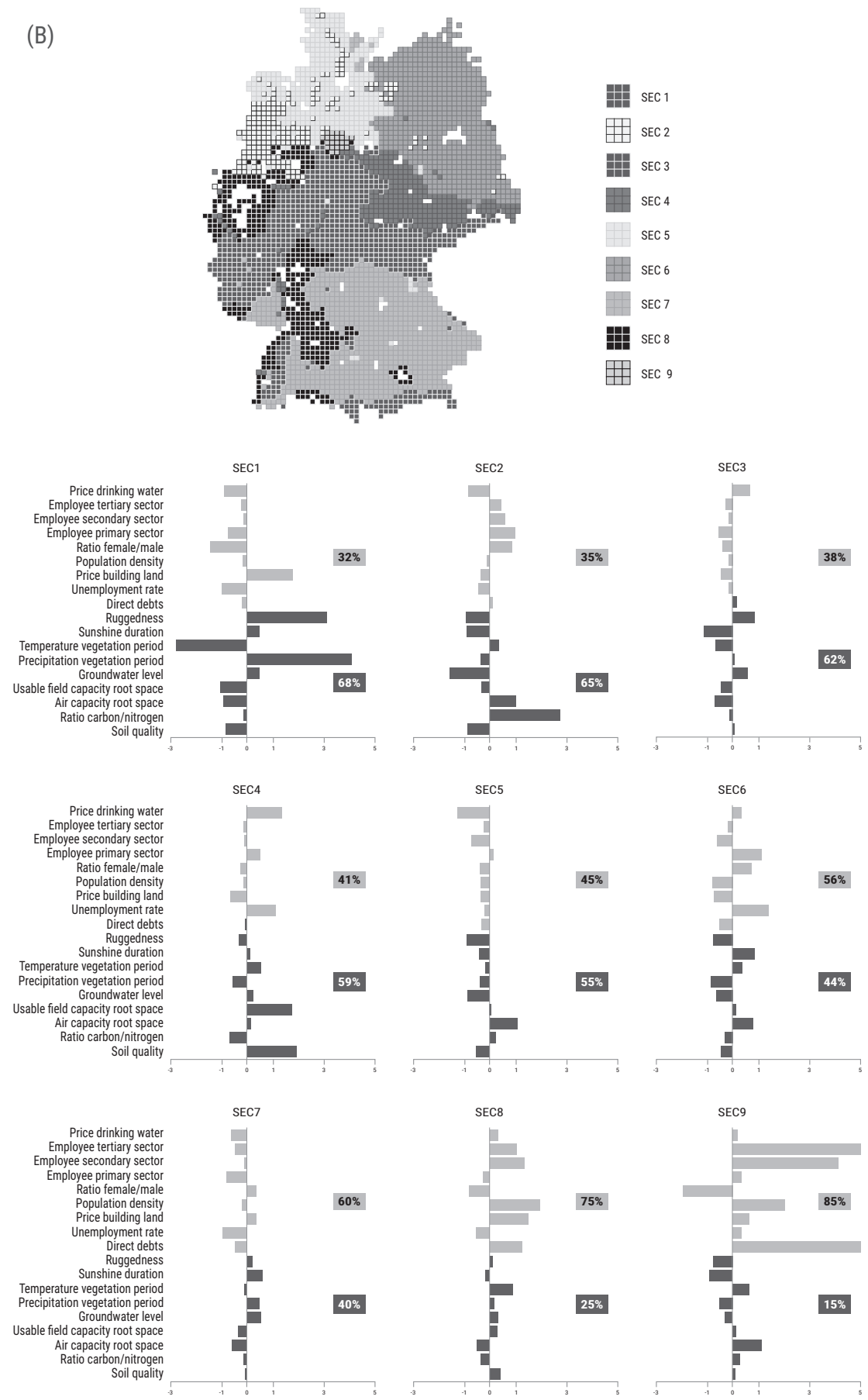

Figure 24.2 Mapped socio-environmental clusters (Dittrich et al. 2017; arcg.is/ 1Caaf50) (@ Ralf Seppelt) 
for migratory birds. It is also noteworthy that the Alpine Mountains are attractive for recreation.

Ecosystem services bundles dominated by cultural ecosystem services overlapped to a wide extent not only with socio-environmental clusters determined by environmental conditions but also with socio-economic conditions. For instance, ESB 8 in Figure 24.3, indicating multi-functional landscapes, overlapped mainly with the intermediate SEC 6, which is characterised by relatively equal levels of both socioeconomic and environmental variables.

The rows in Figure 24.3 sum up to $100 \%$ and the circle sizes illustrate the extent of co-occurrence of the respective socio-economic drivers and ecosystem services bundles. The circles represent the dominance of environmental or socio-economic variables in characterising socio-environmental clusters, whereby colour intensity reflects the degree of dominance (dark = strong; light = weak).

In this case, the absence of pronounced environmental gradients may have hindered a specialisation in certain provisioning services and in turn also prevented known trade-offs with regulating/maintenance services. A spatial stratification of ecosystem services bundles indicated hotspots in which more detailed analysis is needed within national assessments.

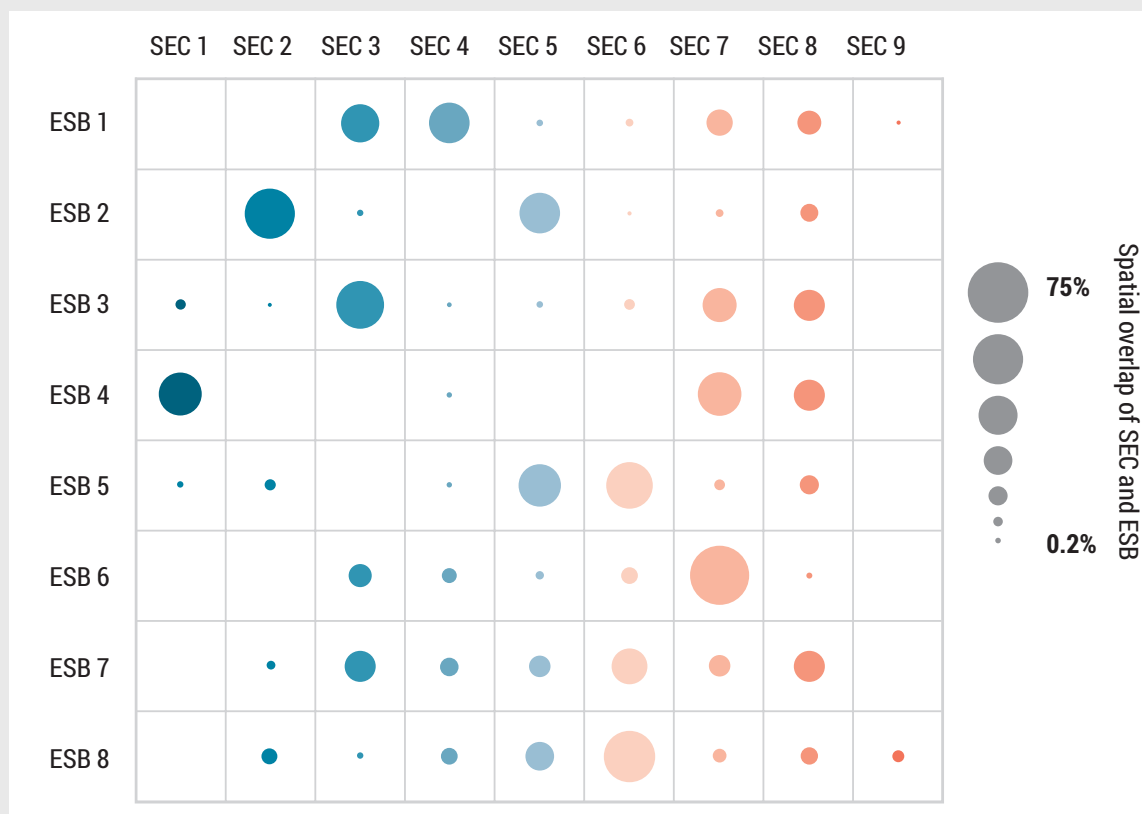

Figure 24.3 Results of spatial overlap analysis of each socio-environmental cluster (SEC) per ecosystem services bundle in percentage of area (Dittrich et al. 2017) 
understand human-nature interactions or 'citizen science' as a tool for intensive data collection and monitoring ecosystem change (Hochachka et al. 2012).

We envisage that spatial mapping and analysis will continue as a rapid growth area in SES research for many years to come, as researchers explore and exploit the many insights it can offer. The field is ripe for the development of new and imaginative approaches to SES analysis that take advantage of new technologies to further develop and test theory.

\section{Key readings}

Cumming, G.S. 2011. Spatial Resilience in Social-Ecological Systems. Dordrecht: Springer.

Ellis, E.C. 2011. 'Anthropogenic Transformation of the Terrestrial Biosphere.' Philosophical Transactions of the Royal Society A: Mathematical, Physical and Engineering Sciences 369: 1010-1035.

Lambin, E.F., H.J. Geist, and E. Lepers. 2003. 'Dynamics of Land-Use and Land-Cover Change in Tropical Regions.' Annual Review of Environment and Resources 28: 205-241.

Levin, S.A. 1992. 'The Problem of Pattern and Scale in Ecology.' Ecology 73: 1943-1967.

Turner, M.G., R.H. Gardner, and R.V. O'Neill. 2015. Landscape Ecology in Theory and Practice: Pattern and Process. New York: Springer.

\section{Acknowledgements}

We thank Andreas Böhme, UFZ, Leipzig, Germany, for the implementation of online visualisation of results from Dittrich et al. (2017).

\section{References}

Agarwal, C., G.M. Green, J. Grove, T.P. Evans, and C.M. Schweik. 2002. 'A Review and Assessment of Land-use Change Models: Dynamics of Space, Time, and Human Choice.' General Technical Report NE-297. Forest Service, US Department of Agriculture.

Agarwal, P., and A. Skupin. 2008. Self-organising Maps: Applications in Geographic Information Science. Hoboken: John Wiley \& Sons.

Ament, J.M., and G.S. Cumming. 2016. 'Scale Dependency in Effectiveness, Isolation, and SocialEcological Spillover of Protected Areas.' Conservation Biology 30: 846-855.

Ban, N.C., M. Mills, J. Tam, C.C. Hicks, S. Klain, N. Stoeckl, M.C. Bottrill et al. 2013. 'A Social-Ecological Approach to Conservation Planning: Embedding Social Considerations.' Frontiers in Ecology and the Environment 11(4): 194-202.

Bodin, Ö., M. Tengö, A. Norman, J. Lundberg, and T. Elmqvist. 2006. 'The Value of Small Size: Loss of Forest Patches and Ecological Thresholds in Southern Madagascar.' Ecological Applications 16: 440-451.

Bonebrake, T.C., C.J. Brown, J.D. Bell, J.L. Blanchard, A. Chauvenet, C. Champion, I.C. Chen, T.D. Clark, R.K. Colwell, and F. Danielsen. 2018. 'Managing Consequences of Climate-driven Species Redistribution Requires Integration of Ecology, Conservation and Social Science.' Biological Reviews 93: 284-305.

Brody, S.D., S.E. Davis, W.E. Highfield, and S.P. Bernhardt. 2008. 'A Spatial-temporal Analysis of Section 404 Wetland Permitting in Texas and Florida: Thirteen Years of Impact along the Coast.' Wetlands 28: 107-116.

Campbell, J.B., and R.H. Wynne. 2011. Introduction to Remote Sensing. New York: Guilford Press.

Cord, A.F., K.A. Brauman, R. Chaplin-Kramer, A. Huth, G. Ziv, and R. Seppelt. 2017. 'Priorities to Advance Monitoring of Ecosystem Services using Earth Observation.' Trends in Ecology and Evolution 32: 416-428.

Cumming, G.S. 2011. Spatial Resilience in Social-Ecological Systems. New York: Springer.

Cumming, G.S., and D.P. van Vuuren. 2006. 'Will Climate Change Affect Ectoparasite Species Ranges?' Global Ecology and Biogeography 15: 486-497.

Dittrich, A., R. Seppelt, T. Václavík, and A.F. Cord. 2017. 'Integrating Ecosystem Service Bundles and Socio-environmental Conditions - A National Scale Analysis from Germany.' Ecosystem Services 28: 273-282. 
Fernández-Giménez, M.E., G.R. Allington, J. Angerer, R.S. Reid, C. Jamsranjav, T. Ulambayar, K. Hondula, B. Baival, B. Batjav, and T. Altanzul. 2018. 'Using an Integrated Social-Ecological Analysis to Detect Effects of Household Herding Practices on Indicators of Rangeland Resilience in Mongolia.' Environmental Research Letters 13: 075010.

Fletcher, R., and M-J. Fortin. 2018. 'Spatial Dependence and Autocorrelation.' In Spatial Ecology and Conservation Modeling: Applications with R, 133-168. New York: Springer.

Franklin, J. 2010. Mapping Species Distributions: Spatial Inference and Prediction. Cambridge: Cambridge University Press.

Gardner, R.H., and D.L. Urban. 2007. 'Neutral Models for Testing Landscape Hypotheses.' Landscape Ecology 22: 15-29.

Geldmann, J., M. Barnes, L. Coad, I.D. Craigie, M. Hockings, and N.D. Burgess. 2013. 'Effectiveness of Terrestrial Protected Areas in Reducing Habitat Loss and Population Declines.' Biological Conservation 161: 230-238.

Hays, G.C., H. Bailey, S.J. Bograd, W.D. Bowen, C. Campagna, R.H. Carmichael, P. Casale, A. Chiaradia, D.P. Costa, and E. Cuevas. 2019. 'Translating Marine Animal Tracking Data into Conservation Policy and Management.' Trends in Ecology and Evolution 34(5): 459-473.

Hebblewhite, M., and D.T. Haydon. 2010. 'Distinguishing Technology from Biology: A Critical Review of the Use of GPS Telemetry Data in Ecology.' Philosophical Transactions of the Royal Society B: Biological Sciences 365: 2303-2312.

Hochachka, W.M., D. Fink, R.A. Hutchinson, D. Sheldon, W.K. Wong, and S. Kelling. 2012. 'Dataintensive Science Applied to Broad-scale Citizen Science.' Trends in Ecology and Evolution 27: 130-137.

Holzhauer, S., C. Brown, and M. Rounsevell. 2019. 'Modelling Dynamic Effects of Multi-scale Institutions on Land Use Change.' Regional Environmental Change 19: 733-746.

Hooten, M.B., D.S. Johnson, B.T. McClintock, and J.M. Morales. 2017. Animal Movement: Statistical Models for Telemetry Data. Boca Raton: CRC press.

Isaaks, E.H., and R.M. Srivastava. 1989. An Introduction to Applied Geostatistics. Oxford: Oxford University Press.

Iwamura, T., E.F. Lambin, K.M. Silvius, J.B. Luzar, and J.M. Fragoso. 2014. 'Agent-based Modeling of Hunting and Subsistence Agriculture on Indigenous Lands: Understanding Interactions between Social and Ecological Systems.' Environmental Modelling and Software 58: 109-127.

Jenerette, G.D., S.L. Harlan, A. Brazel, N. Jones, L. Larsen, and W.L. Stefanov. 2007. 'Regional Relationships between Surface Temperature, Vegetation, and Human Settlement in a Rapidly Urbanizing Ecosystem.' Landscape Ecology 22: 353-365.

Kennedy, R.E., P.A. Townsend, J.E. Gross, W.B. Cohen, P. Bolstad, Y.Q. Wang, and P. Adams. 2009. 'Remote Sensing Change Detection Tools for Natural Resource Managers: Understanding Concepts and Tradeoffs in the Design of Landscape Monitoring Projects.' Remote Sensing of Environment 113: 1382-1396.

Krause, J., S. Krause, R. Arlinghaus, I. Psorakis, S. Roberts, and C. Rutz. 2013. 'Reality Mining of Animal Social Systems.' Trends in Ecology and Evolution 28: 541-551.

Lambin, E.F., and H.J. Geist. 2008. Land-use and Land-cover Change: Local Processes and Global Impacts. New York: Springer.

Lauer, M., and S. Aswani. 2008. 'Integrating Indigenous Ecological Knowledge and Multi-spectral Image Classification for Marine Habitat Mapping in Oceania.' Ocean and Coastal Management 51: 495-504.

Lin, H.Y., C.J. Brown, R.G. Dwyer, D.J. Harding, D.T. Roberts, R.A. Fuller, S. Linke, and H.P. Possingham. 2018. 'Impacts of Fishing, River Flow and Connectivity Loss on the Conservation of a Migratory Fish Population.' Aquatic Conservation: Marine and Freshwater Ecosystems 28: 45-54.

Liu, J., T. Dietz, S.R. Carpenter, M. Alberti, C. Folke, E. Moran, A.N. Pell, P. Deadman, T. Kratz, and J. Lubchenco. 2007. 'Complexity of Coupled Human and Natural Systems.' Science 317: 1513-1516.

Magris, R.A., M. Andrello, R.L. Pressey, D. Mouillot, A. Dalongeville, M.N. Jacobi, and S. Manel. 2018. 'Biologically Representative and Well-connected Marine Reserves Enhance Biodiversity Persistence in Conservation Planning.' Conservation Letters 11(4): e12439.

Magris, R.A., R.L. Pressey, M. Mills, D.A. Vila-Nova, and S. Floeter. 2017. 'Integrated Conservation Planning for Coral Reefs: Designing Conservation Zones for Multiple Conservation Objectives in Spatial Prioritisation.' Global Ecology and Conservation 11: 53-68.

Margules, C.R., and R.L. Pressey. 2000. 'Systematic Conservation Planning. Nature 405: 243. 
Mets, K.D., D. Armenteras, and L.M. Dávalos. 2017. 'Spatial Autocorrelation Reduces Model Precision and Predictive Power in Deforestation Analyses.' Ecosphere 8: e01824.

Meyfroidt, P., R.R. Chowdhury, A. de Bremond, E.C. Ellis, K-H. Erb, T. Filatova, R.D. Garrett et al. 2018. 'Middle-range Theories of Land System Change.' Global Environmental Change 53(August): 52-67. doi:10.1016/j.gloenvcha.2018.08.006.

Moorcroft, P.R., and M.A. Lewis 2013. Mechanistic Home Range Analysis (MPB-43). Princeton: Princeton University Press.

Mouchet, M.A., P. Lamarque, B. Martín-López, E. Crouzat, P. Gos, C. Byczek, and S. Lavorel. 2014. 'An Interdisciplinary Methodological Guide for Quantifying Associations between Ecosystem Services.' Global Environmental Change 28: 298-308.

Newton, A.C., R.A. Hill, C. Echeverria, D. Golicher, J.M.R. Benayas, L. Cayuela, and S.A. Hinsley. 2009. 'Remote Sensing and the Future of Landscape Ecology.' Progress in Physical Geography 33: 528-546.

Oppel, S., M. Bolton, A.P. Carneiro, M.P. Dias, J.A. Green, J.F. Masello, R.A. Phillips. E.Owen, P. Quillfeldt, and A. Beard. 2018. 'Spatial Scales of Marine Conservation Management for Breeding Seabirds.' Marine Policy 98: 37-46.

Ord, J.K. 2010. 'Spatial Autocorrelation: A Statistician's Reflections.' In Perspectives on Spatial Data Analysis, edited by L. Anselin and S.J. Rey, 165-180. New York: Springer.

Overmars, K.D., G. de Koning, and A. Veldkamp. 2003. 'Spatial Autocorrelation in Multi-scale Land Use Models.' Ecological Modelling 164: 257-270.

Poiani, K.A., B.D. Richter, M.G. Anderson, and H.E. Richter. 2000. 'Biodiversity Conservation at Multiple Scales: Functional Sites, Landscapes, and Networks.' BioScience 50: 133-146.

Possingham, H., I. Ball, and S. Andelman. 2000. 'Mathematical Methods for Identifying Representative Reserve Networks.' In Quantitative Methods for Conservation Biology, edited by S. Ferson and M. Burgman, 291-305. New York: Springer.

Pressey, R.L., M. Cabeza, M.E. Watts, R.M. Cowling, and K.A. Wilson. 2007. 'Conservation Planning in a Changing World.' Trends in Ecology and Evolution 22: 583-592.

Ridding, L.E., J.W. Redhead, T.H. Oliver, R. Schmucki, J. McGinlay, A.R. Graves, J. Morris, R.B. Bradbury, H. King, and J.M. Bullock. 2018. 'The Importance of Landscape Characteristics for the Delivery of Cultural Ecosystem Services.' Journal of Environmental Management 206: 1145-1154.

Sherrouse, B.C., D.J. Semmens, and J.M. Clement. 2014. 'An Application of Social Values for Ecosystem Services (SolVES) to Three National Forests in Colorado and Wyoming.' Ecological Indicators 36: 68-79.

Short, R., R. Gurung, M. Rowcliffe, N. Hill, and E.J. Milner-Gulland. 2018. 'The Use of Mosquito Nets in Fisheries: A Global Perspective.' PLoS ONE 13: e0191519.

Skellam, J.G. 1951. 'Random Dispersal in Theoretical Populations.' Biometrika 38: 196-218.

Trasarti, R., A-M. Olteanu-Raimond, M. Nanni, T. Couronné, B. Furletti, F. Giannotti, Z. Smoreda, and C. Ziemlicki. 2015. 'Discovering Urban and Country Dynamics from Mobile Phone Data with Spatial Correlation Patterns.' Telecommunications Policy 39: 347-362.

Turner, M.G., R.H. Gardner, and R.V. O’Neill. 2001. Landscape Ecology in Theory and Practice: Pattern and Process. New York: Springer.

Uden, D.R., C.R. Allen, D.G. Angeler, L. Corral, and K.A. Fricke. 2015. 'Adaptive Invasive Species Distribution Models: A Framework for Modeling Incipient Invasions.' Biological Invasions 17: 2831-2850.

Veldkamp, A., and E.F. Lambin. 2001. Predicting Land-use Change. Amsterdam: Elsevier.

Von Humboldt, A., and A. Bonpland. 1807 (reprint 2010). Essay on the Geography of Plants, edited by S.T. Jackson, 296. Chicago: University of Chicago Press.

Zetterberg, A., U.M. Mörtberg, and B. Balfors. 2010. 'Making Graph Theory Operational for Landscape Ecological Assessments, Planning, and Design.' Landscape and Urban Planning 95: 181-191. 